\title{
Photonic Real-Time Monitoring of Bacterial Reduction in Root Canals by Genetically Engineered Bacteria after Chemomechanical Endodontic Therapy
}

\author{
Aguinaldo Silva GARCEZ ${ }^{1}$ \\ Silvia Cristina NUNEZ ${ }^{1}$ \\ José Luis LAGE-MARQUES ${ }^{2}$ \\ Michael R. HAMBLIN ${ }^{3}$ \\ Martha Simões RIBEIRO ${ }^{1}$ \\ ${ }^{1}$ Center of Lasers and Applications, IPEN-CNEN/SP, São Paulo, SP, Brazil \\ ${ }^{2}$ School of Dentistry, University of São Paulo, São Paulo, SP, Brazil \\ ${ }^{3}$ Harvard-MIT, Division of Health Sciences and Technology, Cambridge, Massachusetts, USA
}

\begin{abstract}
Microbial infection plays an important role in the development of pulp necrosis and formation of periapical lesions. In vitro and in vivo research in this field, traditionally microbiological culture methods using paper point sampling and quantitative culture, faces difficulties in completely removing bacteria from the root canal system and analyzing sequential procedures. This study employed genetically engineered bioluminescent bacteria and a light-sensitive imaging system to allow real-time visualization of the infection. Ten extracted teeth incubated with $P$. aeruginosa were treated by mechanical instrumentation with K-files (\#30 K-file, \#35 K-file and \#40 K-file) and chemical irrigation with sodium hypochlorite and hydrogen peroxide. Irrigation alone reduced the contamination in $18 \%$; the first chemomechanical sequence (instrumentation with a \#30 K-file + irrigation) provided $41 \%$ of reduction; the second sequence (\#35 Kfile + irrigation) achieved 62\%; and the complete therapy (\#30 K-file + \#35 K-file + \#40 K-file + irrigation) achieved 93\% of bacterial reduction. These results suggest that the endodontic treatment is dependent on the association of a chemical and mechanical approaches and that root canal enlargement improves bacterial reduction probably because the irrigation has more access to the apical third.
\end{abstract}

Key Words: bacteria, root canals, chemomechanical endodontic therapy.

\section{INTRODUCTION}

Elimination of the pathogenic micro-flora from the root canal system during endodontic therapy is one of the main goals of endodontic treatment. Microbial infection plays an important role in the development of dental pulp necrosis and formation of periapical lesions (1). It is well established that the eradication of intracanal bacteria is difficult, and current endodontic techniques are unable to consistently disinfect the the root canal systems (2). Accepted treatment procedures to eliminate the infection include root canal debridement and mechanical shaping or smoothing (3), irrigation with disinfectant agents, such as sodium hypochlorite or hydrogen peroxide, application of an interappointment intracanal dressing containing an antimicrobial agent and finally, root canal sealing (4).

It has been shown that, when a negative microbiological culture is obtained from the root canal at the time of obturation, there is a $94 \%$ success rate. On the other hand, when obturation is performed and the cultures are positive, success rate is reduced to $68 \%$, which confirms previous data of a higher failure incidence with poor healing in cases with periapical lesion. 
In vitro and in vivo research in this field traditionally involves microbiological culture methods using paper points to collect samples from the root canals and quantitative culture assays. These methods present some difficulties, such as the lack of a complete withdraw of the bacterial load from root canal. In addition, it is virtually impossible to analyse sequential procedures without destroying the samples, which means that investigating sequential procedures with these methods is realistically imprecise.

Recently, a non-destructive method to study the efficacy of sequential antimicrobial therapeutical procedures in both ex vivo and in vivo studies has been developed (5). This method uses real-time optical bioluminescence imaging employing sensitive low light cameras to visualize and quantify photon emission from the bioluminescent reporter strain of a bioluminescent bacterium after it has been inoculated (6). Bioluminescent bacteria have been successfully applied for real-time monitoring of infections (7). Bioluminescence emission from the infected animal or growth substrate can be correlated with cell counts obtained using homogenization/extraction and conventional culturing methods. The primary advantage of this approach over alternative methods is that it provides real-time quantitative assessment of bacterial burden as opposed to qualitative assessment of bacterial load displaced onto paper points, swabs, extracted from part of the sample or visualized by electron microscopy. Moreover, bioluminescent bacteria can be quantified over sequential procedures without destroying the sample (8). Research groups have employed bioluminescent imaging as a convenient means to monitor the effectiveness of antisepsis in animal models of infections caused by several bioluminescent pathogens (9). This methodology has been demonstrated in mouse models of infected wounds $(10,11)$, burns (12), abscesses (14), and in dentistry, for endodontic treatment (14) using both Gram-positive and Gram-negative bacteria.

In this study, a procedure using bioluminescent genetically engineered bacteria and a light-sensitive imaging system was employed to allow real-time visualization of infections within the root canals. When antimicrobial therapies are employed, bacteria lose their luminescence and the light emission loss occurs in parallel with the loss of colony-forming ability, while the emitted light quantification indicates the bacterial reduction achieved from the procedure. The purpose of this study was to assess the bacterial reduction within the root canal system promoted by a chemomechanical endodontic therapy on a 3-day biofilm formed with bioluminescent Gram-negative bacteria.

\section{MATERIAL AND METHODS}

\section{Root Canals}

Ten human single-rooted teeth (maxillary central incisors and canines) with straight canals confirmed radiographically freshly extracted for periodontal reasons were collected and stored in sterile saline until use. The crowns were removed with a diamond disc and the roots were shortened to a length of approximately 13 $\mathrm{mm}$. The canals were enlarged to an apical size of a \#30 K-file (Maillefer Instruments SA, Ballaigues, Switzerland) and irrigated with $10 \mathrm{~mL}$ of $2.5 \%$ sodium hypochlorite at each change of file. The external root surfaces were sealed with two layers of nail polish to avoid environmental contamination.

The apical foramen was subsequently sealed with composite resin (Filtek Z-250; 3M/ESPE, St. Paul MN, USA). The root canals were irrigated with $17 \%$ EDTA for 2 min followed by irrigation with PBS solution for smear layer removal (14). Prior to inoculation, the specimens were autoclaved for $15 \mathrm{~min}$ at $121^{\circ} \mathrm{C}$.

\section{Bacterial Strain and Growth Conditions}

Pseudomonas aeruginosa (XEN5) that had been engineered to be stably bioluminescent by transformation with a transposon containing the entire Photorhabdus luminescens lux operon (15) were kindly donated by Xenogen Corp. (Alameda, CA, USA).

Bacteria were grown in brain heart infusion (BHI) broth at $37^{\circ} \mathrm{C}$ with shaking $(150 \mathrm{rpm})$ to form a stationary growth phase suspension of 1 x 109 cells/ $\mathrm{mL}$. Ten $\mu \mathrm{L}$ of this suspension was added to each root canal and each tooth was placed inside a $1.5-\mathrm{mL}$ microcentrifuge tube that was subsequently sealed and kept upright and incubated for $72 \mathrm{~h}$ at $37^{\circ} \mathrm{C}$ with shaking to allow biofilm formation. After $72 \mathrm{~h}$, bioluminescence imaging of each tooth inside its transparent microcentrifuge tube was carried out with a low-light intensified camera (Hamamatsu Photonics KK, Bridgewater, NJ, USA). The use of this imaging system 
has been described in detail in a previous work (10). Briefly, bioluminescence signal was accumulated for 2 min at 35 sensitivity level and a maximum setting on the image intensifier control module. Using ARGUS software (Siemens Medical Solutions, Erlangen, Germany) the luminescence image was presented as a false-color image superimposed on top of the grayscale reference image. The image-processing component of the software gave mean pixel values from the luminescence images on defined areas covering each tooth on a 256grayscale. For bioluminescen cecomparisons, all images were recorded at same bit-range. These images served to confirm the level of infection and to obtain the initial signal from the bacteria inside the root canals.

\section{Endodontic Procedure}

Before instrumentation, the root canals were irrigated with $5 \mathrm{~mL}$ of $2.5 \%$ sodium hypochlorite followed by $5 \mathrm{~mL}$ of $3 \%$ hydrogen peroxide to remove all BHI medium growth and to lubricate the canals. Then, conventional root canal instrumentation with backwards and forwards moviments was performed using a sequence of 3 endodontic file sizes (\#30, \#35 and \#40 K-files; Maillefer Instruments SA). The canals were irrigated with $5 \mathrm{~mL}$ of $2.5 \%$ sodium hypochlorite followed by $5 \mathrm{~mL}$ of $3 \%$ hydrogen peroxide between each file using a 28 -gauge needle and a syringe. The teeth were held inverted during irrigation to prevent external contamination of root surface by overflowing irrigant. Bioluminescence imaging was performed after each procedure (initial irrigation, hand instrumentation and irrigation with both chemical solutions) and at treatment completion (14). Descriptive statistical analyses were performed by the mean values of pixel counting obtained from each sample. The results are expressed as means and error bars are standard errors.

\section{RESULTS}

In order to use bioluminescence imaging as a surrogate marker of bacterial burden or bacterial viability, it is necessary to be able to correlate the strength of the luminescence signal emitted from the bacterial cells with number of colony forming units (CFU). The loss of viability curves, as measured by CFU and by luminescence loss as a function of the time and time of incubation of the bacteria with the antimicrobial agent is presented in Figure 1.

The loss of luminescence showed the same time-response curve shape as loss of CFU, but the absolute reductions were 2 logs minus. The reasons for this discrepancy are likely to be the following. Firstly, The limit of sensitivity of the luminescence assay with the plate reader is a $3 \log$ reduction in signal, while the CFU assay can measure up to a $6 \log$ reduction in viability. Secondly, it appears that the cytotoxic insult to the bacteria causes loss of viability more readily than the loss of luminescence. The mechanism by which luminescence decreases after antimicrobial disinfection is uncertain, but it may be due to exhaustion or loss of the luciferase substrate, loss of the energy source (reduced flavin mononucleotide) or chemical damage to the luciferin enzyme. Nevertheless, the data show that the measured reductions in luminescence are likely if anything to underestimate the actual extent of bacterial killing in the root canals.

\section{Development of the Root-Canal Infection Model}

The addition of $10-\mu \mathrm{L}$ of a suspension containing $10^{8}$ cells of $P$. aeruginosa into the root canals followed by 3 -day incubation at $37^{\circ} \mathrm{C}$ reliably and reproducibly produced a bioluminescent biofilm that

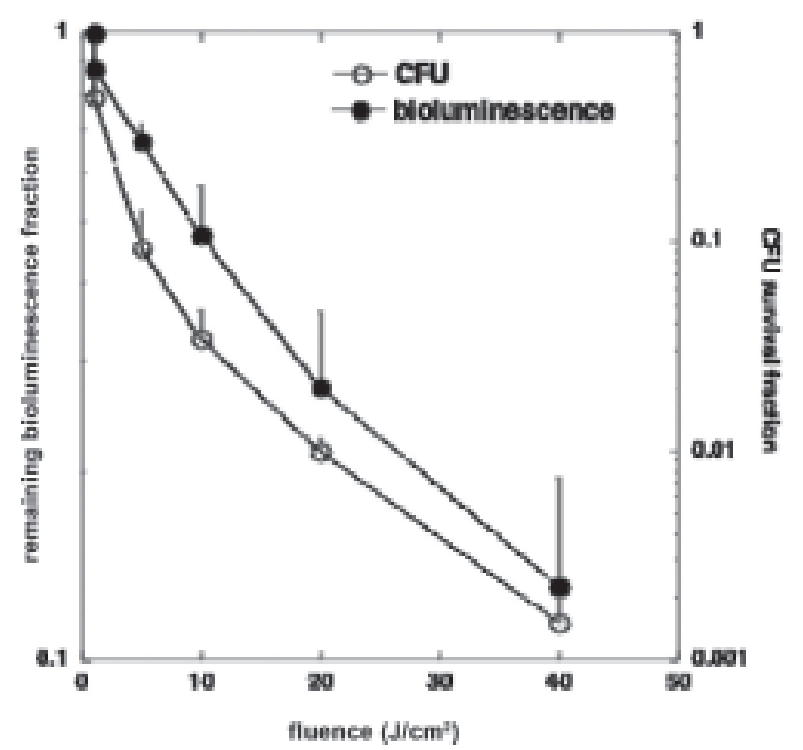

Figure 1. Correlation between the loss of viability curves by CFU and by loss of luminescence. 
could be imaged through the width of the tooth material. There were minor variations from tooth to tooth in the pattern of the detected luminescence, which was probably due to differences in the root canal system geometry of each tooth. The presence of a microbial biofilm rather than planktonic bacteria was demonstrated by the failure of irrigation with saline to significantly diminish the luminescence signal (data not shown).

\section{Bacterial Reduction}

In the present stdudy, the experiments were carried out by root canal chemomechanical instrumentation and measuring of bioluminescence signal after each procedure. There was a sequence-dependent reduction in bioluminescence until a cumulative result was reached when further instrumentation ceased to have a noticeable effect.

Figure 2 shows the percentage of bacterial reduction after each step of the treatment.

Irrigation alone reduced the bacterial contamination in $18 \%$; the first chemomechanical sequence (instrumentation with \#30 K-file + irrigation) achieved $41 \%$ of reduction; the second sequence (instrumentation with \#35 K-file + irrigation) achieved $62 \%$; and the complete therapy (instrumentation with \#30 K-file + \#35 K-file + \#40 K-file + irrigation) promoted $93 \%$ of bacterial reduction.

\section{DISCUSSION}

The aim of this study was to develop a real-time

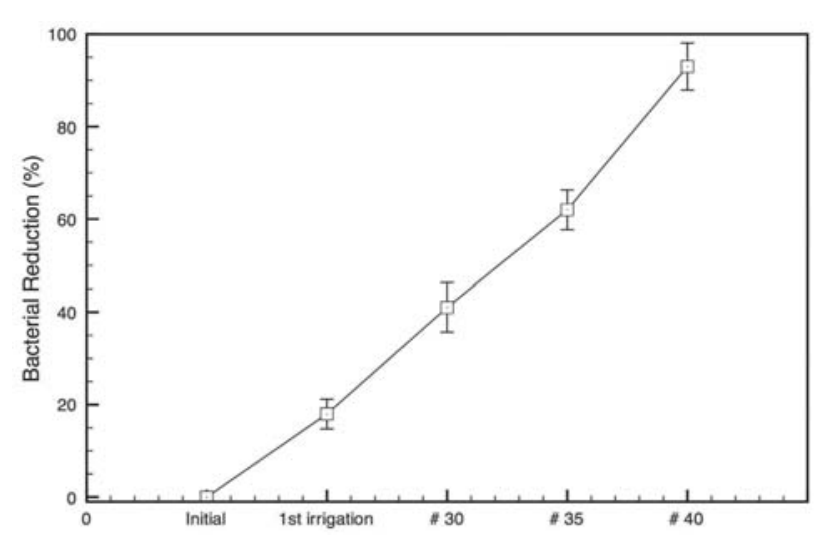

Figure 2. Bacterial reduction (\%) after each step of the treatment. method using bioluminescent bacteria and a low-light imaging camera to evaluate the antimicrobial effects of root canal treatment. It also quantitatively compared the effect of sequential steps of a conventional endodontic treatment on Gram-negative bacterial biofilm.

$P$. aeruginosa was selected for this investigation based on its strong bioluminescence activity and propensity to form biofilms. There are reports of $P$. aeruginosa (16) being isolated as endodontic infectious agents. Their morphology (Gram-negative rods with 2$3 \mu \mathrm{m}$ in length) is highly similar to that of other Gramnegative rods commonly found in endodontic infections (17). In addition to bacteria classification, their ability to grow as biofilm seems to be an important determinant of bacterial resistance to antimicrobial therapies as well as endodontic virulence (18). In this work, the cells were grown for $72 \mathrm{~h}$ to allow biofilm formation, which is expected to increase the difficulty of the antimicrobial challenge in a closely approach to real-life situations.

Because the bioluminescence imaging method is non-invasive, the comparative evaluation of more than one procedure was possible. Sequential images were obtained for each tooth, allowing statistical analysis with low inter-sample variation. The method is an alternative to traditional in vitro culture methods using paper point sampling and quantitative culture, and further supports previous reports on the difficulties in completely eliminating bacteria from the root canal system.

A previous study of our research group (14) used this methodology to quantify the bacterial reduction after photodynamic antimicrobial therapy associated with endodontic treatment. That study showed a correlation of the photo-reduction of two gram negative bacteria, (P. aeruginosa and P. mirabilis) and CFU count. The reduction was dose dependent and the realtime quantification of the antimicrobial effect of the sequence of irradiation could determine the optimal dose for endodontic photodynamic therapy.

Sedgley et al. developed a bioluminescent model of root canal infection using Pseudomonas fluorescens $5 \mathrm{RL}$, which is a strain containing a lux CDABE plasmid that is inducible with salicylate. They determined the correlation between bioluminescent signal and extracted CFU. This group used this model to study the effect of varying the needle depth during endodontic irrigation (19). In another study (20), the same group of investigators, using the model described above, showed bacterial reduction after irrigation and concluded that me- 
chanical efficacy of irrigation in reducing intracanal bacteria is dependent upon the canal preparation size, and shape.

The results of the present study are consistent with the outcomes of these previous investigations. When the root canal was enlarged up to a K-file of greater size, the irrigation needle could penetrate deeper and closer to the apical portion and, in these cases, bacterial reduction was improved. This clearly demonstrated that the entire sequence of increased diameter files and irrigation is important to achieve a cumulative greater disinfection.

The use of $5 \mathrm{~mL}$ of sodium hypochlorite and hydrogen peroxide, resulting in a $10-\mathrm{mL}$ irrigation, is in accordance with Sedgley et al. (20), who showed that the use of at least $6 \mathrm{~mL}$ is necessary to significantly remove bacteria from the root canals. Also the chemical combination of the two solution promote a well know reaction (Fenton reaction) that produce reactive oxygen species that improve the bacterial reduction.

Figure 2 shows the linear reduction of $P$. aeruginosa from the root canals. These data can be explained by the increase of canal enlargement, which facilitates irrigant access and also removes lodged bacteria mechanically. Again, it can be observed the importance of the final canal diameter to allow an intimate contact of the chemical solution at the apical portion of the root canal, improving bacterial killing.

The fist irrigation achieve only $18 \%$ of reduction probably because bacteria were still in a biofilm configuration. Bacterial biofilm has a complex architecture that is much more resistant to antimicrobial therapy than planktonic bacteria. Irrigation after the first step of K-file instrumentation was more effective possibly because instrument action disrupted the bacterial biofilm, increasing the antimicrobial effect of the chemical irrigant. It also provided removal of contaminated dentin chips, yielding a significant reduction of the bacterial load.

The data of the present study confirm those of previous investigations and indicate that the use of bioluminescent images is an effective methodology to monitoring bacterial reduction within root canal. The findings hereby reported suggest that the endodontic treatment is dependent on the association of a chemomechanical approach and that root canal enlargement provides a better access to the apical portion, thus actually improving bacterial reduction.

\section{RESUMO}

Infecções microbianas são um dos fatores principais no desenvolvimento de necrose pulpar e lesões periapicais. Tradicionalmente, estudos in vivo e in vitro utilizam cultura microbiológica com coletas com cones de papel e quantificação de unidades formadoras de colônia. A maior desvantagem deste método é a dificuldade de se remover as bactérias dos canais radiculares e a impossibilidade de promover a análise seqüencial deste procedimento. Este estudo empregou bactérias geneticamente modificadas para apresentarem bioluminescência e um sistema sensível a baixa luminosidade, permitindo a visualização em tempo-real da área infectada. Dez dentes extraídos foram incubados com $P$. aeruginosa e tratados endodonticamente com instrumentação mecânica com limas K (\#30, \#35 e \#40) e irrigação com hipoclorito de sódio e peróxido de hidrogênio. A irrigação sozinha reduziu a contaminação inicial em $18 \%$; a primeira seqüência de lima e irrigação (lima \#30) obteve $41 \%$ de redução; a segunda seqüência (lima \#35 e irrigação) obteve 62\%; e o tratamento completo (lima \#30, lima \#35, lima \#40 e irrigação) reduziu a contaminação bacteriana inicial em $93 \%$. Os resultados sugerem que o tratamento endodôntico é dependente da associação dos procedimentos químico-mecânicos que promovem o alargamento do canal radicular, otimizando a redução microbiana, possivelmente devido ao maior acesso das substâncias químicas à porção apical do canal radicular.

\section{REFERENCES}

1. Siqueira JF Jr. Endodontic infections: concepts, paradigms, and perspectives. Oral Surg Oral Med Oral Pathol Oral Radiol Endod 2002;94:281-293.

2. Bonsor SJ, Nichol R, Reid TM, Pearson GJ. Microbiological evaluation of photo-activated disinfection in endodontics (an in vivo study). Br Dent J 2006;200:337-341.

3. Bahcall JK, Barss JT. Understanding and evaluating the endodontic file. Gen Dent 2000;48:690-692.

4. Sedgley C. Root canal irrigation-a historical perspective. J Hist Dent 2004;52:61-65.

5. Doyle TC, Burns SM, Contag CH. In vivo bioluminescence imaging for integrated studies of infection. Cell Microbiol 2004;6:303-317.

6. Contag CH, Contag PR, Mullins JI, Spilman SD, Stevenson DK, Benaron DA. Photonic detection of bacterial pathogens in living hosts. Mol Microbiol 1995; 18:593-603.

7. Burns SM, Joh D, Francis KP, Shortliffe LD, Gruber CA, Contag PR, Contag CH. Revealing the spatiotemporal patterns of bacterial infectious diseases using bioluminescent pathogens and whole body imaging. Contrib Microbiol 2001;9:71-88.

8. Doyle TC, Burns SM, Contag CH. In vivo bioluminescence imaging for integrated studies of infection. Cell Microbiol 2004;6:303-317.

9. Demidova TN, Gad F, Zahra T, Francis KP, Hamblin MR. Monitoring photodynamic therapy of localized infections by bioluminescence imaging of genetically engineered bacteria. $\mathrm{J}$ Photochem Photobiol B 2005;81:15-25.

10. Hamblin MR, O'Donnell DA, Murthy N, Contag CH, Hasan T. Rapid control of wound infections by targeted photodynamic therapy monitored by in vivo bioluminescence imag- 
ing. Photochem Photobiol 2002;75:51-57.

11. Hamblin MR, Zahra T, Contag CH, McManus AT, Hasan T. Optical monitoring and treatment of potentially lethal wound infections in vivo. J Infect Dis 2003;187:1717-1726.

12. Lambrechts SA, Demidova TN, Aalders MC, Hasan T, Hamblin MR. Photodynamic therapy for Staphylococcus aureus infected burn wounds in mice. Photochem Photobiol Sci 2005;4:503-509.

13. Gad F, Zahra T, Francis KP, Hasan T, Hamblin MR. Targeted photodynamic therapy of established soft-tissue infections in mice. Photochem Photobiol Sci 2004;3:451-458.

14. Garcez AS, Ribeiro MS, Tegos GP, Nunez SC, Jorge AO, Hamblin MR. Antimicrobial photodynamic therapy combined with conventional endodontic treatment to eliminate root canal biofilm infection. Lasers Surg Med 2007;39:59-66.

15. Maoz A, Mayr R, Bresolin G, Neuhaus K, Francis KP, Scherer $\mathrm{S}$. Sensitive in situ monitoring of a recombinant bioluminescent Yersinia enterocolitica reporter mutant in real time on Camembert cheese. Appl Environ Microbiol 2002;68:57375740 .
16. Ranta K, Haapasalo M, Ranta H. Monoinfection of root canal with Pseudomonas aeruginosa. Endod Dent Traumatol 1988;4:269-272.

17. Haapasalo M, Ranta H, Ranta KT. Facultative gram-negative enteric rods in persistent periapical infections. Acta Odontol Scand 1983;41:19-22.

18. Distel JW, Hatton JF, Gillespie MJ. Biofilm formation in medicated root canals. J Endod 2002;28:689-693.

19. Sedgley C, Applegate B, Nagel A, Hall D. Real-time imaging and quantification of bioluminescent bacteria in root canals in vitro. J Endod 2004;30:893-898.

20. Sedgley CM, Nagel AC, Hall D, Applegate B. Influence of irrigant needle depth in removing bioluminescent bacteria inoculated into instrumented root canals using real-time imaging in vitro. Int Endod J 2005;38:97-104.

Accepted September 24, 2007 